\title{
Emissions from Co-firing Lignite and Biomass in an Oxy-fired CFBC
}

\author{
Murat Varol ${ }^{\mathrm{a}, \mathrm{b}}$, Robert Symonds ${ }^{\mathrm{c}}$, E.J. Anthony, ${ }^{\mathrm{c}, \mathrm{d},}$, Dennis Lu ${ }^{\mathrm{c}}$, Lufei Jia ${ }^{\mathrm{c}}$, Yewen Tan ${ }^{\mathrm{c}}$ \\ ${ }^{a}$ Department of Environmental Engineering, Middle East Technical University, Ankara, 06800, Turkey \\ ${ }^{b}$ Department of Environmental Engineering, Akdeniz University, Antalya, 07058, Turkey (present address) \\ ${ }^{c}$ Natural Resources Canada, CanmetENERGY, 1 Haanel Drive, Ottawa, ON K1A 1M1, Canada \\ ${ }^{d}$ Cranfield University, Cranfield, Bedfordshire MK43 OAL, United Kingdom \\ ${ }^{*}$ Corresponding author. Tel.: 44(0)1234111 x2823; Fax: 44(0)7853 167530+.

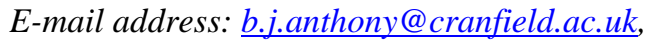

\begin{abstract}
:
The co-combustion of a high-sulphur lignite and biomass blend (up to $50 \%$ by weight) has been studied in a small oxy-fired circulating fluidized bed combustion (CFBC) pilot plant. Here the goal is to examine the effect of biomass share on $\mathrm{NO}_{\mathrm{x}}, \mathrm{SO}_{2}$ and $\mathrm{CO}$ emissions. In these tests, a series of runs has looked at the effect of increasing biomass share under air firing, followed by tests in oxyfiring mode. The results show that the emissions are remarkably insensitive to the biomass share, and are comparable to other results for coal combustion, and likely to be well below any current emission guidelines. Overall, there appear to be no direct challenges to oxy-fuel co-firing in terms of gaseous emissions, although the simple lack of studies means that significantly more data are required on CFBC oxy-firing using a much wider range of biomass and coal types. $\mathrm{K}$ doping was also examined and did not result in significant formation of $\mathrm{K}$ phases on deposit probes.
\end{abstract}

Keywords: oxy-firing, circulating fluidized bed combustion, emissions, co-firing

\section{Highlights:}

- CO emissions are less than $400 \mathrm{ppm}$ in all tests and are lower in the case of co-firing and comparable to or better than levels seen for air-fired CFB work.

- $\mathrm{NO}_{\mathrm{x}}$ levels were consistently between 100-200 ppm and co-firing did not appear to significantly affect them up to a biomass share of $50 \%$.

- Changing from air- to oxygen-firing decreased the efficiency of $\mathrm{SO}_{2}$ capture.

- K doping did not produce significant $\mathrm{K}$ containing deposits on deposit probes.

- Hydrocarbon emissions for oxy-firing were generally extremely low. 


\section{Introduction}

Oxy-fuel combustion is one of the most promising routes for using fossil fuels in a $\mathrm{CO}_{2}$-neutral manner. When combined with biomass firing it may also offer net reductions of $\mathrm{CO}_{2}$ emissions, the so-called BioEnergy with Carbon Storage (BECS) option [Toftegaard et al., 2010; Cormos, 2016]. Here fluidized bed combustion is arguably the best available co-firing technology [Leckner, 2007], and it has recently been demonstrated in its oxy-combustion form at the $30 \mathrm{MW}_{\text {th }}$ scale at Ciuden, in Spain [Anthony and Hack, 2013; Lupion et al., 2013]. However, despite rapid advances in the technology, there are remarkably few studies on the co-firing of biomass and coal in an oxy-fuel circulating fluidized bed combustion (CFBC) environment [Tan et al., 2013; Varol et al., 2014a,b; Duan et al., 2015] and, for that matter, relatively few papers on the operation of oxy-fuel CFBC [Jia et al., 2007, 2010; Romeo et al., 2011; Tan et al., 2013; Singh and Kumar, 2016] in general. Moreover, the necessity for recycling flue gas, in order to control the temperature in the primary reaction loop, means higher emission levels in the flue gases with the potential for fouling, corrosion and other problems [Jia et al., 2012; Tan et al., 2012]. Given the interest in the potential for achieving negative $\mathrm{CO}_{2}$ emissions [Bui et al., 2017], and the very successful oxy-fuel CFBC trials carried out by Foster Wheeler at Ciuden, in Spain, there is a need to accelerate such developments. To do this we must explore a wide range of coals and biomass products in order to investigate the behavior of oxy-fuel CFBC technology with a range of feedstocks beyond the three co-firing studies currently available, which were carried out on a $0.4 \mathrm{~m}$ dia. CFBC [Tan et al., 2013], and a $0.1 \mathrm{~m}$ dia. CFBC [Varol et al., 2014a,b], respectively. In this work, a Spanish lignite was used and K doping was adopted for the oxy-fuel trials, to simulate the co-combustion of Turkish lignite and olive cake which typically contains high levels of $\mathrm{K}$. It was anticipated that emissions would be similarly low compared with our previous studies, and that $\mathrm{K}$ doping would not influence those emissions. Less certain was whether the $\mathrm{K}$ doping would lead to measurable fouling or the production of agglomerates.

\section{Materials and Methods}

\subsection{Characteristics of Fuels and Limestone}

A Spanish lignite and wood pellets (obtained from a commercial supplier (Valfei) in Canada) were used in this study. The proximate and ultimate analyses of these fuels are given in Table 1. In all combustion tests, the lignite particle size was less than $4.76 \mathrm{~mm}$ and the wood pellets were approximately $20 \mathrm{~mm}$ in length and $5 \mathrm{~mm}$ in diameter.

Havelock limestone from Canada, which is a high-purity limestone $\left(>98 \% \mathrm{CaCO}_{3}\right)$, was also used to examine $\mathrm{SO}_{2}$ emissions under co-firing conditions. Havelock has been used extensively in other FBC work at CanmetENERGY and elsewhere [Lu et al., 2009; Al-Jeboori et al., 2013].

Table 1. Proximate and ultimate analyses of Spanish lignite and wood pellets

Spanish lignite

Wood pellets

\section{Proximate analysis, \% by wt. (as fired)}

\begin{tabular}{ccc}
\hline FC & 29.26 & 15.40 \\
\hline VM & 29.36 & 80.17 \\
\hline Ash & 28.40 & 0.4 \\
\hline Moisture & 12.98 & 4.03 \\
\hline
\end{tabular}


Ultimate analysis, \% by wt. (dry basis)

\begin{tabular}{ccc}
\hline $\mathbf{C}$ & 44.4 & 49.6 \\
\hline $\mathbf{H}$ & 2.92 & 5.92 \\
\hline $\mathbf{N}$ & 0.52 & 0.13 \\
\hline $\mathbf{S}_{\text {total }}$ & 5.72 & \\
\hline $\mathbf{O}$ & 13.83 & 03.93 \\
\hline $\mathbf{A s h}$ & 32.64 & 0.42 \\
\hline $\mathbf{H H V}, \mathbf{k J} / \mathbf{k g}$ (as fired) & 14,600 & 18,900 \\
\hline
\end{tabular}

FC: Fixed Carbon, VM: Volatile Matter, HHV: Higher Heating Value

\subsection{Experimental}

Combustion tests were carried out in a lab-scale circulating fluidized bed combustor located at Natural Resources Canada - CanmetENERGY in Ottawa, Canada. The schematic diagram of the experimental setup is shown in Figure 1. The experimental setup consists of a combustor, a cyclone, a return leg, a bag filter and a feeding system. The feeding system is comprised of two fuel hoppers for lignite and wood pellets. Limestone was added to the system by mixing it with lignite. The combustor is constructed of SS310 steel and has an internal diameter of $0.1 \mathrm{~m}$, and height of $5.1 \mathrm{~m}$. It is fitted with electric heaters capable of operating at temperatures up to $1100{ }^{\circ} \mathrm{C}$. This facility has been described in detail elsewhere [Jia et al., 2007, 2010; Symonds et al., 2016]. 


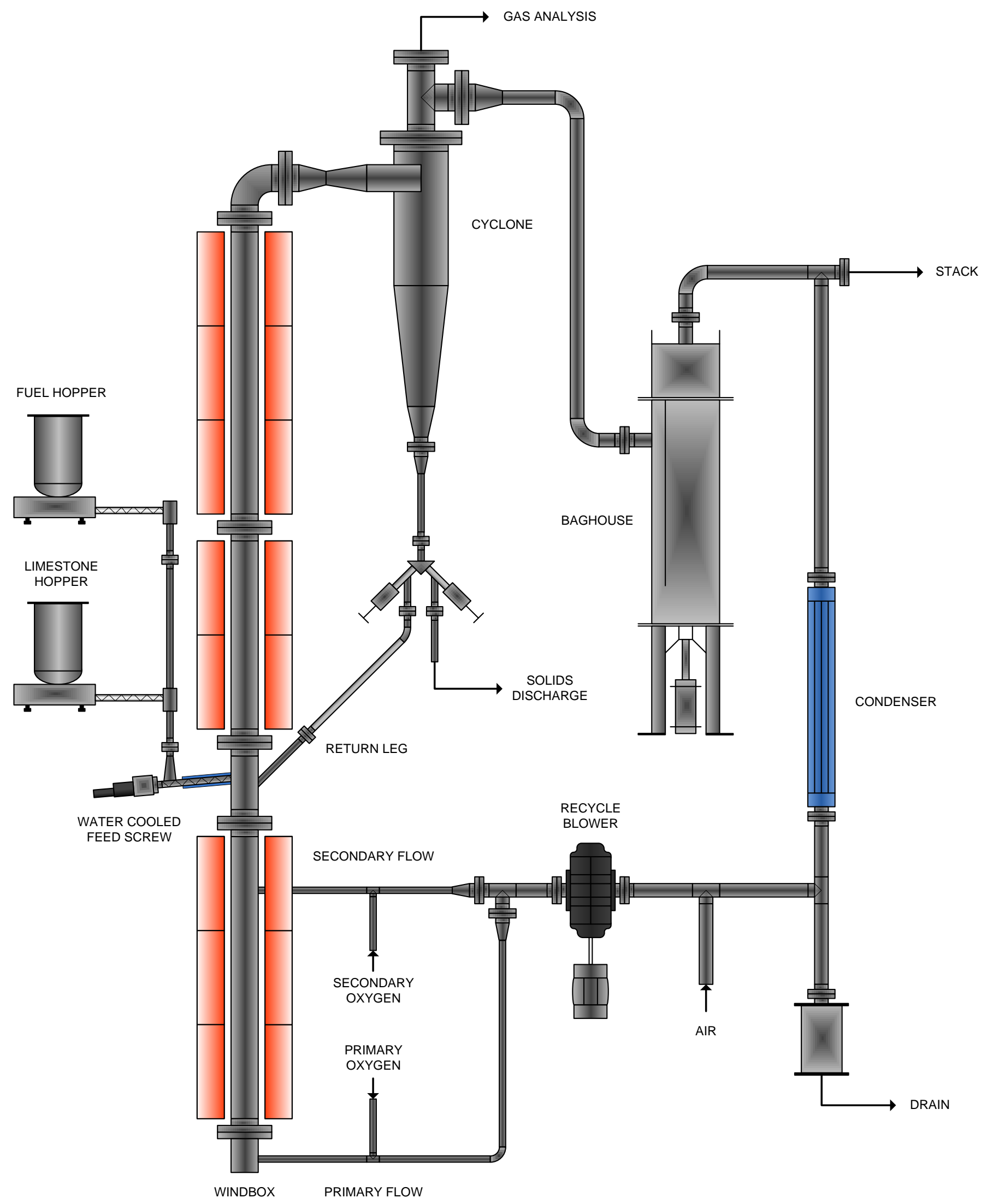

Figure 1. Schematic of Natural Resources Canada - CanmetENERGY Mini Bed CFBC 
In all, eight tests of several hours duration were carried out in order to determine the effect of biomass share, $\mathrm{O}_{2}$ percentage in the combustion gas and dense phase bed temperature on flue gas emissions. Five of these tests were air-fired and the remaining tests were oxy-fuel-fired. The experimental matrix consists of three different experimental sets which are described in Table 2. All but one of these tests were done at $850^{\circ} \mathrm{C}$, with a final test carried out at $915^{\circ} \mathrm{C}$ to determine the effect of temperature. Both the percentage of biomass and the oxygen in the recirculated flue gas were varied, and the three distinct campaigns are as shown in Table 2. Here, no attempt was made to keep the heat input constant; instead the mass fraction of biomass was changed (10, 30 and 50\% weight) by changing the coal feed rate accordingly. Secondary air was not used, and all emission figures in the tables and figures have been re-calculated to $6 \% \mathrm{O}_{2}$.

Table 2. Experimental Matrix

\begin{tabular}{cccccc}
$\begin{array}{c}\text { Test } \\
\#\end{array}$ & $\begin{array}{c}\text { Run } \\
\text { designation }\end{array}$ & $\begin{array}{c}\text { Ca:S } \\
\text { molar } \\
\text { ratio }\end{array}$ & $\begin{array}{c}\text { Biomass Share of Fuel } \\
\text { Mixture } \\
(\% \text { by wt. })\end{array}$ & $\begin{array}{c}\text { Nominal } \\
\mathbf{O}_{2} \\
(\mathbf{v o l . \%})\end{array}$ & $\begin{array}{c}\text { Bed Temperature } \\
\mathbf{T}_{\text {dense phase }} \\
(\mathbf{6} \mathbf{C})\end{array}$ \\
\hline $1-1$ & C-1 & 2 & 0 & air-fired & 850 \\
\hline $1-2$ & CB-1 & 2 & 10 & air-fired & 850 \\
\hline $1-3$ & CB-2 & 2 & 30 & air-fired & 850 \\
\hline $1-4$ & CB-3 & 2 & 50 & air-fired & 850 \\
\hline $2-1$ & CB-4 & 2 & 50 & air-fired & 850 \\
\hline $2-2$ & CB-5 & 2 & 50 & 25 & 850 \\
\hline $2-3$ & CB-6 & 3 & 50 & 30 & 850 \\
\hline $3-1$ & CB-7* & - & 50 & 30 & 850 \\
\hline $3-2$ & CB-8* & 3 & 50 & 30 & 915 \\
\hline $3-3$ & CB-9* & 3 & 50 & 30 & \\
\hline
\end{tabular}

* With K doping.

The first campaign was carried out in an air-fired mode to determine the effect of biomass share on flue gas emissions. In these tests both temperature in the dense bed $\left(\mathrm{T}_{\text {dense phase }}\right)$ and superficial velocity in the combustor were kept effectively constant, at about $850^{\circ} \mathrm{C}$ and between 2.5 and $3 \mathrm{~m} / \mathrm{s}$, respectively, as far as possible. The experiments involved combustion of Spanish lignite, and co-combustion of Spanish lignite and wood pellet fuel mixtures containing $0,10,30$, and $50 \%$ by weight of wood pellets (Tests no. 1-1 to 1-4).

In the second campaign the tests were designed to determine the effect of $\mathrm{O}_{2}$ percentage in the combustion gas on emission levels in the flue gas. The experiments included co-combustion of Spanish lignite and wood pellets $\left(1: 1\right.$ weight ratio) for two different oxygen levels fed to the combustor $\left(25 \%\right.$ and $\left.30 \% \mathrm{O}_{2}\right)$ (Tests no. 2-2 and 2-3) and these results are compared along with those for air firing (Test no. 2-1).

In the last campaign, three experiments were conducted to investigate the effect of biomass and limestone interaction and bed temperature on ash composition and deposit formation under oxy-firing conditions (30\% $\mathrm{O}_{2}$ ). Three tests (3-1, 3-2 and 3-3) were carried out with $\mathrm{K}$ doping bringing the $\mathrm{K}_{2} \mathrm{O}$ content in the "biomass 
ash" to an overall 34-39\%. This is roughly equivalent to levels associated with Turkish olive cake, which is a potentially important fuel in Turkey since it produces about $8 \%$ of the world's olives [Demirbas, 2009]. All three tests were carried out for a nominal $24 \mathrm{~h}$ period. To simulate the $\mathrm{K}$ effect, $\mathrm{K}_{2} \mathrm{CO}_{3}$ solution was sprayed onto the wood pellets, which were then air dried prior to feeding. The amount of $\mathrm{K}_{2} \mathrm{CO}_{3}$ added was based on the ash content of the wood pellets and the K content typical of olive cake ash.

Spanish lignite/wood pellets $\left(1: 1\right.$ weight ratio) mixture was oxy-fired $\left(30 \% \mathrm{O}_{2}\right)$ at $850^{\circ} \mathrm{C}$ in Test no. $3-1$. Test no. 3-2 was the same test with limestone addition (0-2 mm particle size). Tests no. 3-1 and 3-2 were used to see the effect of limestone addition to the fuel mixture on ash composition. The third test (Test no. 33 ) in this campaign was a repeat of test 3-2 with the operating temperature raised to $915^{\circ} \mathrm{C}$ to see the effect of dense phase temperature on ash composition.

In order to carry out this work, a special "deposit sampling probe" was designed and manufactured to simulate a heat exchanger tube in the combustor (Figure 2). The surface of the deposit sampling probe is cooled internally down to $550^{\circ} \mathrm{C}$ with air in order to represent the surface temperature of the superheaters. The deposit sampling probe was used in order to collect fly ash samples during the combustion process. The particles accumulated on the probe's surface were collected at the end of the test. After the probe was removed from the combustor, the particles collected on the probe were very slowly scraped from the surface into a sampling pot. The deposit sampling probe itself was located at a level of $4.5 \mathrm{~m}$ above the distributor plate. The probe was made from a stainless steel tube with a $26.7 \mathrm{~mm}$ outer diameter (OD) and its length was $230 \mathrm{~mm}$. The deposit samples themselves accumulated on the surface of the probe on the detachable ring which has a length of $60 \mathrm{~mm}$, and a $26.7 \mathrm{~mm}$ OD. The probe temperature at this level was around 790$830{ }^{\circ} \mathrm{C}$ for the tests where dense phase temperature was kept at a nominal $850{ }^{\circ} \mathrm{C}(\mathrm{C}-1, \mathrm{CB}-1$ to $\mathrm{CB}-8)$, and a temperature of $845^{\circ} \mathrm{C}$ for the test where dense phase temperature was kept at $915^{\circ} \mathrm{C}(\mathrm{CB}-9)$.
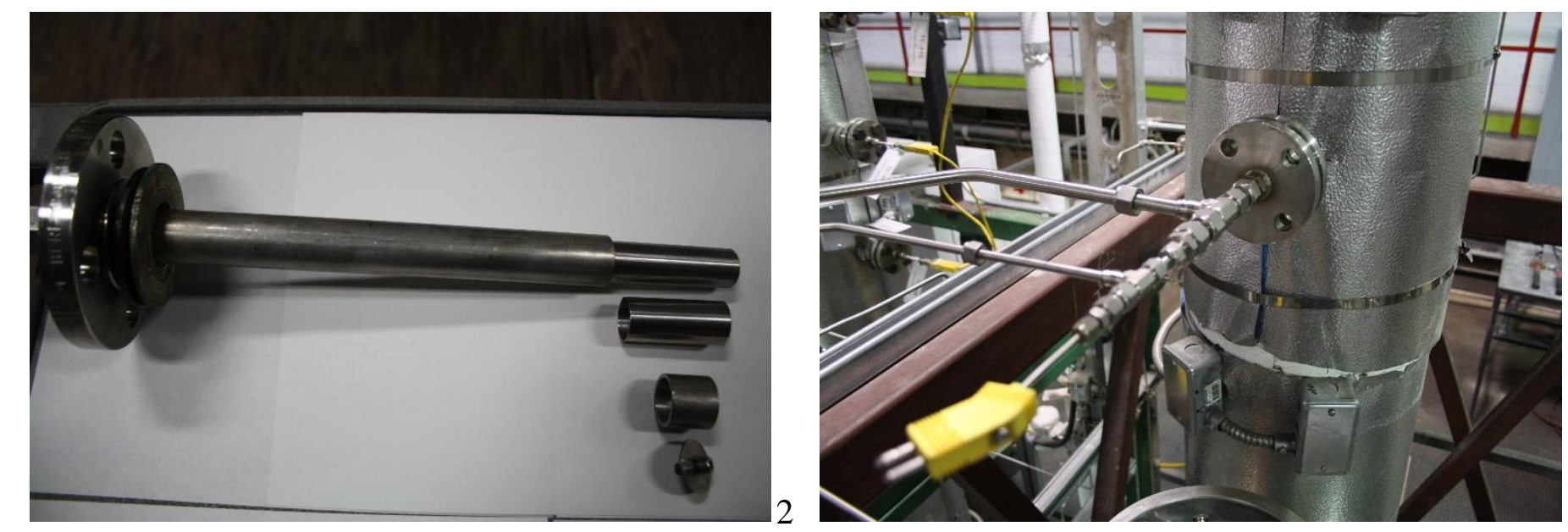

Figure 2. Air cooled deposit sampling probe with a detachable ring

The deposit characteristic X-ray diffraction (XRD) data were collected on a Rigaku Ultima IV XRD spectrometer over the angular range 7 to $80^{\circ}$ (2-theta) in $0.02^{\circ}$ steps at 1 degree/min. The XRD system operates in the theta:theta geometry, uses $\mathrm{Cu}(\mathrm{K} \alpha)$ radiation, $0.154 \mathrm{~nm}$. The generator voltage and current settings were $40 \mathrm{kV}$ and $44 \mathrm{~mA}$, respectively. At the end of the co-combustion tests (Tests no 3-1 to 3-3), bed ash from the combustor and fly ash from the bag filter were collected. X-ray fluorescence (XRF) and XRD analyses of ash samples were carried out. 
The diffraction spectra were processed using the JADE version 9.0 XRD processing software. Identification of the chemical or mineral compounds was performed using the search/match option in JADE. Accurate integrated intensities of diffraction peaks were derived through "peak deconvolution" or more commonly called "line profile fitting", another software tool in JADE. These data were used for quantitative analysis. Quantitative analysis of the samples was done using a variety of different internal spiking standards. This technique is known as the reference intensity ratio (RIR) method. For quantitative XRD, each sample was mixed with a spiking agent. The resulting mixture was thoroughly ground using a mortar and pestle to ensure homogeneity of the phases. The resulting powdered mixture was loaded into a holder. The holder was transferred to the XRD instrument and data were collected. Integrated intensities for strong diffracting peaks of each phase were obtained using JADE. Concentrations of the chemicals identified in each sample were calculated using the method mentioned above. The amorphous content was estimated by difference.

For this work EPA Method 0031 was used for volatile organic compounds (VOC) sampling. The VOC sampling train consists of a heated glass-lined probe, two sorbent tubes containing Tenax ${ }^{\circledR}-\mathrm{GC}(1.6 \pm 0.1 \mathrm{~g}$ each), a third sorbent tube containing Anasorb®-747 $(5.0 \mathrm{~g} \pm 0.1 \mathrm{~g})$, flow measurement and other related devices. Once steady state operation of the oxy-fuel mini-CFB was achieved, flue gas samples were pumped through the VOC sampling train. As the flue gas passed through the sorbent tubes, VOCs were absorbed onto the Tenax and the Anasorb sorbents. At the end of the VOC sampling period, the sorbent cartridges were analyzed to determine the amount of each volatile organic compound absorbed. Together with the volume of flue gas sample passing through the VOC sampling train, concentrations of VOCs were determined.

\section{Results and Discussion}

\subsection{Effect of Biomass Share on Emissions}

Four tests were conducted in order to determine the effect of wood pellets on major pollutants in flue gas $\left(\mathrm{CO}_{2}, \mathrm{CO}, \mathrm{NO}_{\mathrm{x}}\right.$, and $\left.\mathrm{SO}_{2}\right)$. Here the percentage of biomass by weight was varied $(0 \%, 10 \%, 30 \%$, and $50 \%)$ and $\mathrm{CO}_{2}$ levels were typically around $15-16 \%$. Limestone was used in all combustion tests at a $\mathrm{Ca} / \mathrm{S}$ ratio of 2.

The effect of the proportion of wood pellets in the fuel mixture on $\mathrm{CO}_{2}, \mathrm{CO}, \mathrm{SO}_{2}$, and $\mathrm{NO}_{\mathrm{x}}$ emissions is shown in Table 3, 4 and 5 and Figure 3. Here $\lambda$ is excess air.

Table 3. Emissions for Air-Fired Coal/Biomass Mixtures (all emissions expressed to $6 \% \mathrm{O}_{2}$ )

\begin{tabular}{lcccccccccc} 
Run & $\begin{array}{c}\text { Coal } \\
\text { feed rate } \\
(\mathbf{k g} / \mathbf{h})\end{array}$ & $\begin{array}{c}\text { Biomass } \\
\text { feed rate } \\
(\mathbf{k g} / \mathbf{h})\end{array}$ & $\begin{array}{c}\text { Air } \\
\text { flow } \\
\text { rate } \\
(\mathbf{k g} / \mathbf{h})\end{array}$ & $\boldsymbol{\lambda}$ & $\begin{array}{c}\mathbf{C O}_{2} \\
(\mathbf{v o l . \%})\end{array}$ & $\begin{array}{c}\mathbf{C O} \\
(\mathbf{p p m})\end{array}$ & $\begin{array}{c}\mathbf{N O}_{\mathbf{x}} \\
(\mathbf{p p m})\end{array}$ & $\begin{array}{c}\text { \% N } \\
\text { conversion }\end{array}$ & $\begin{array}{c}\mathbf{S O}_{2} \\
(\mathbf{p p m})\end{array}$ & $\begin{array}{c}\text { \% } \mathbf{S} \\
\text { capture }\end{array}$ \\
\hline $\mathrm{C}-1$ & 6 & 0 & 15.8 & 1.49 & $15.5 \pm 0.8$ & $86 \pm 12$ & $131 \pm 13$ & 3.7 & $977 \pm 130$ & $89 \%$ \\
\hline $\mathrm{CB}-1$ & 4.2 & 0.47 & 18.0 & 1.50 & $15.5 \pm 0.8$ & $59 \pm 5$ & $144 \pm 13$ & 6.4 & $806 \pm 72$ & $85 \%$ \\
\hline $\mathrm{CB}-2$ & 3.22 & 1.38 & 18.8 & 1.37 & $15.3 \pm 0.7$ & $30 \pm 7$ & $120 \pm 7$ & 6.7 & $410 \pm 87$ & $89 \%$ \\
\hline $\mathrm{CB}-3$ & 2.02 & 2.02 & 22.1 & 1.50 & $15.4 \pm 1.2$ & $56 \pm 15$ & $120 \pm 19$ & 11.0 & $303 \pm 83$ & $85 \%$ \\
\hline
\end{tabular}

Table 4. Emissions for Air-Fired Coal/Biomass Mixtures (all emissions expressed to $6 \% \mathrm{O}_{2}$ )

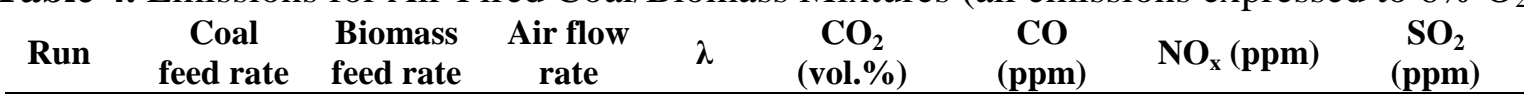




\begin{tabular}{ccccccccc} 
& $\mathbf{( k g / h )}$ & $\mathbf{( k g / h )}$ & $\mathbf{( k g / h )}$ & & & & & \\
\hline CB-4 & 2.02 & 2.02 & 22.1 & 1.50 & $15.4 \pm 1.2$ & $56 \pm 15$ & $120 \pm 19$ & $303 \pm 83$ \\
\hline CB-5 & 2.27 & 2.27 & 17.2 & 1.22 & $83.0 \pm 7.1$ & $316 \pm 261$ & $116 \pm 18$ & $2354 \pm 387$ \\
\hline CB-6 & 2.29 & 2.27 & 11.4 & 1.15 & $81.1 \pm 5.5$ & $410 \pm 289$ & $121 \pm 25$ & $779 \pm 288$ \\
\hline
\end{tabular}

$* \overline{\mathrm{CB}}-4$ and $\mathrm{CB}-3$ are the same test.

Table 5. Emissions for Air-Fired Coal/Biomass Mixtures (all emissions expressed to $6 \% \mathrm{O}_{2}$ )

\begin{tabular}{ccccccccc} 
Run & $\begin{array}{c}\text { Coal } \\
\text { feed rate } \\
(\mathbf{k g} / \mathbf{h})\end{array}$ & $\begin{array}{c}\text { Biomass } \\
\text { feed rate } \\
(\mathbf{k g} / \mathbf{h})\end{array}$ & $\begin{array}{c}\text { Air flow } \\
\text { rate } \\
(\mathbf{k g} / \mathbf{h})\end{array}$ & $\boldsymbol{\lambda}$ & $\begin{array}{c}\mathbf{C O}_{2} \\
(\mathbf{v o l . \%})\end{array}$ & $\begin{array}{c}\mathbf{C O} \\
(\mathbf{p p m})\end{array}$ & $\mathbf{N O}_{\mathbf{x}}(\mathbf{p p m})$ & $\begin{array}{c}\mathbf{S O}_{\mathbf{2}} \\
(\mathbf{p p m})\end{array}$ \\
\hline $\mathrm{CB}-8$ & 2.29 & 2.27 & 11.4 & 1.15 & $81.1 \pm 5.5$ & $410 \pm 289$ & $121 \pm 25$ & $779 \pm 288$ \\
\hline $\mathrm{CB}-9$ & 2.52 & 2.52 & 12.9 & 1.12 & $85.3 \pm 3.8$ & $436 \pm 288$ & $110 \pm 20$ & $1416 \pm 425$ \\
\hline
\end{tabular}

$*$ CB- 8 and CB-6 are the same test.

Average $\mathrm{CO}$ emission was about $86 \mathrm{ppm}$ for lignite (only) combustion. However, $\mathrm{CO}$ emissions decreased with an increasing share of wood pellets in the fuel mixture and reached a minimum value of less than 50 ppm for a fuel mixture containing 30\% wood pellets. Interestingly, a further increase in the share of wood pellets increased $\mathrm{CO}$ emissions to above $50 \mathrm{ppm}$, but still below the $86 \mathrm{ppm}$ value seen for lignite combustion alone. However, these results do not seem out of line with those for a well-run air-fired CFBC plant.

Due to the relative $\mathrm{S}$ contents of the two fuels, $\mathrm{SO}_{2}$ emissions decreased with an increase in the share of wood pellets in the fuel mixture from values above $1000 \mathrm{ppm}$ for $100 \%$ lignite combustion to $300 \mathrm{ppm}$ for fuel mixtures containing 50\% wood pellets and here limestone performance was remarkably consistent. More surprisingly, in the case of $\mathrm{NO}_{\mathrm{x}}$ emissions, the wood pellets appeared to have a fairly small effect on the emissions in terms of ppm, but a much larger effect on the overall nitrogen conversions. $\mathrm{NO}_{\mathrm{x}}$ emissions were consistently between $100 \mathrm{ppm}$ and $150 \mathrm{ppm}$ for all cases despite the fact that the fuel nitrogen in the biomass is only a quarter of that for the lignite. A possible explanation is that, as the coal fraction drops significantly, so does the char carbon and, despite the fall-off in fuel nitrogen, the bed's ability to reduce $\mathrm{NO}_{\mathrm{x}}$ starts to decline. This phenomenon was previously observed by Leckner and Karlsson [1993] in cofiring coal and biomass tests in a $12 \mathrm{MW}_{\text {th }}$ CFBC. 


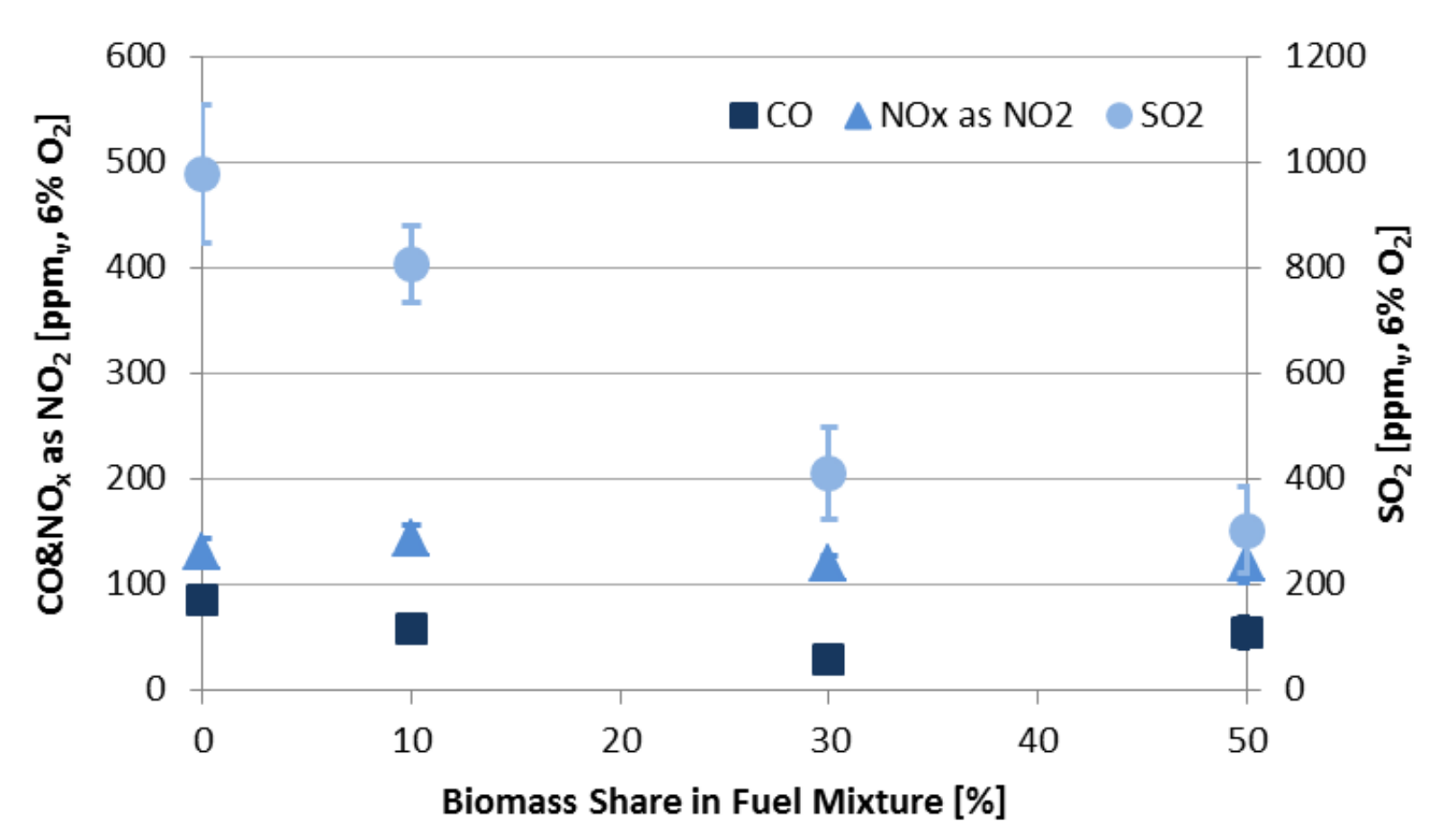

Figure 3. Effect of biomass share in fuel mixture on $\mathrm{CO}_{2}, \mathrm{CO}, \mathrm{SO}_{2}$, and $\mathrm{NO}_{\mathrm{x}}$ emissions under air-firing combustion conditions

\subsection{Effect of $\mathrm{O}_{2}$ Concentration on Emissions}

The effect of the $\mathrm{O}_{2}$ percentage in the combustion gas on $\mathrm{CO}_{2}, \mathrm{CO}, \mathrm{SO}_{2}$, and $\mathrm{NO}_{\mathrm{x}}$ emissions for the cocombustion of wood pellets (50\% by wt.) and Spanish lignite is shown in Figure 3. Three co-combustion tests with $21 \%$ (by vol.), 25\% (by vol.) and $30 \%$ (by vol.) of $\mathrm{O}_{2}$ were conducted. For the oxy-firing tests $\mathrm{CO}_{2}$ rose from $15 \%$ for the air-fired case to around $82 \%$ for the $30 \% \mathrm{O}_{2}$ case.

In the case of air-firing $\left(21 \% \mathrm{O}_{2}\right)$ with $50 \%$ biomass, $\mathrm{SO}_{2}$ emissions were about $300 \mathrm{ppm}$ due to indirect sulphation (Eqn. 1). However, they increased dramatically to $2300 \mathrm{ppm}$ with $25 \% \mathrm{O}_{2}$ because of flue gas recirculation and presumably the fact that sulphation then occurred via the direct route (Eqn. 2). The average temperature of the dense phase region was $844^{\circ} \mathrm{C}, 850^{\circ} \mathrm{C}$, and $853^{\circ} \mathrm{C}$ for $21 \%, 25 \%$ and $30 \% \mathrm{O}_{2}$, respectively. Simple equilibrium calculations suggest that, for $82 \% \mathrm{CO}_{2}$ in the flue gas, sulphation should be via the direct route since the partial pressure of $\mathrm{CO}_{2}$ should be approximately $50 \mathrm{kPa}$, while at $915^{\circ} \mathrm{C}$ the partial pressure of $\mathrm{CO}_{2}$ over $\mathrm{CaCO}_{3}$ is $137 \mathrm{kPa}$, so sulphation must be by the indirect route [Stanmore, 2005] and qualitative XRD (QXRD) measurements on the bed ash also confirmed that the bulk of the Ca component was in the form of $\mathrm{CaO}$.

$\mathrm{CaO}+\mathrm{SO}_{2}+1 / 2 \mathrm{O}_{2}=\mathrm{CaSO}_{4}$

$\mathrm{CaCO}_{3}+\mathrm{SO}_{2}+1 / 2 \mathrm{O}_{2}=\mathrm{CaSO}_{4}+\mathrm{CO}_{2}$

It seems reasonably well established at this point that $\mathrm{SO}_{2}$ emissions are likely to be higher for direct sulphation than for indirect sulphation [Jia et al., 2007, 2010; García-Labiano et al., 2011; Lupiáñez et al., 2013; Tan et al., 2012]. 


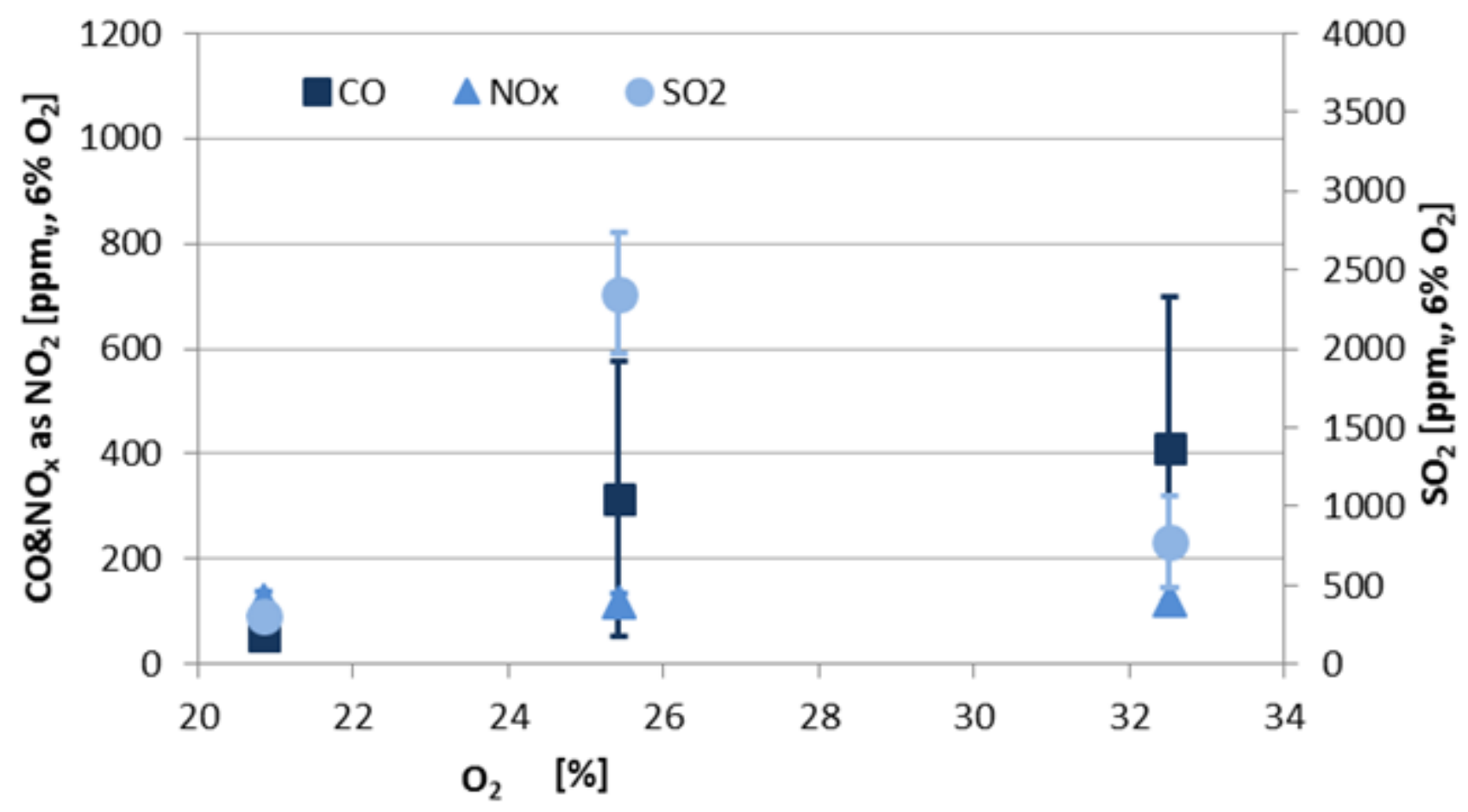

Figure 4. Effect of $\mathrm{O}_{2}$ percentage on $\mathrm{CO}, \mathrm{SO}_{2}$, and $\mathrm{NO}_{\mathrm{x}}$ emissions for the co-combustion of wood pellets (50\% by wt.) and Spanish lignite (Ca:S molar ratio was 3 for 32\% O2 result)

In the case of a nominal $30 \% \mathrm{O}_{2}, \mathrm{SO}_{2}$ emission was measured as $780 \mathrm{ppm}$ which was lower than that for $25 \% \mathrm{O}_{2}(2300 \mathrm{ppm})$. This is partially due to the increased $\mathrm{Ca}: \mathrm{S}$ molar ratio from 2 to 3 , but the change is still rather high. After the $\mathrm{SO}_{2}$ emission results obtained from the experiment with $25 \% \mathrm{O}_{2}$, it was decided to increase the $\mathrm{Ca} / \mathrm{S}$ ratio because the maximum range of the gas analyzer for $\mathrm{SO}_{2}$ was $3000 \mathrm{ppm}$. The summary of these tests is shown in Figure 4.

Interestingly, $\mathrm{NO}_{\mathrm{x}}$ emissions were between $100 \mathrm{ppm}$ and $150 \mathrm{ppm}$ for all cases and it is clear that the percentage of $\mathrm{O}_{2}$ in the primary gas supplied to the base of the combustor had no effect on $\mathrm{NO}_{\mathrm{x}}$ emission. However, the $\mathrm{CO}$ levels rose considerably above those from the air-fired case, reaching values around 400 ppm. These values are about double those seen in the work of Tan et al. [2013] and this is probably due to the smaller scale of the oxy-fuel combustor used in this work, and possible differences in cyclone design, as earlier work on this oxy-fuel combustor indicated that $\mathrm{CO}$ emissions are very sensitive to cyclone operation [Jia et al., 2010]. However, it is worth noting that all the CO results are comparable to those of Varol et al. [2014a] when firing a high-sulphur Turkish lignite and wood pellets in a $0.1 \mathrm{~m}$ dia. oxy-CFB unit, whose values were between $165-530 \mathrm{ppm}$.

\subsection{Effect of Temperature on Emissions}

The effect of operating temperature on $\mathrm{CO}_{2}, \mathrm{CO}, \mathrm{SO}_{2}$, and $\mathrm{NO}_{\mathrm{x}}$ emissions for the co-combustion of wood pellets (50\% by wt.) and Spanish lignite was examined by increasing the bed temperature (Figure 5). Tests were conducted at $850^{\circ} \mathrm{C}$ and $915^{\circ} \mathrm{C}$. The oxygen percentage in the gas was about $30 \%$ and the $\mathrm{Ca} / \mathrm{S}$ ratio was 3 for both runs. While operating with an increase in temperature from $850^{\circ} \mathrm{C}$ to $915^{\circ} \mathrm{C}$ is associated with only a slight increase in $\mathrm{CO}_{2}$ levels $(82 \%$ vs. $85 \%)$, it has a large effect on $\mathrm{SO}_{2}$ emissions which increased from about $780 \mathrm{pm}$ to around $1410 \mathrm{ppm}$, which is reasonable if one assumes that despite the fact that 
indirect sulphation is expected to be better than direct sulphation, the temperature is beyond the peak for optimum sulphur capture in the indirect mode [Anthony and Granatstein, 2001]. By contrast, the higher temperature levels do not appear to influence the $\mathrm{CO}$ and $\mathrm{NO}_{\mathrm{x}}$ emissions.

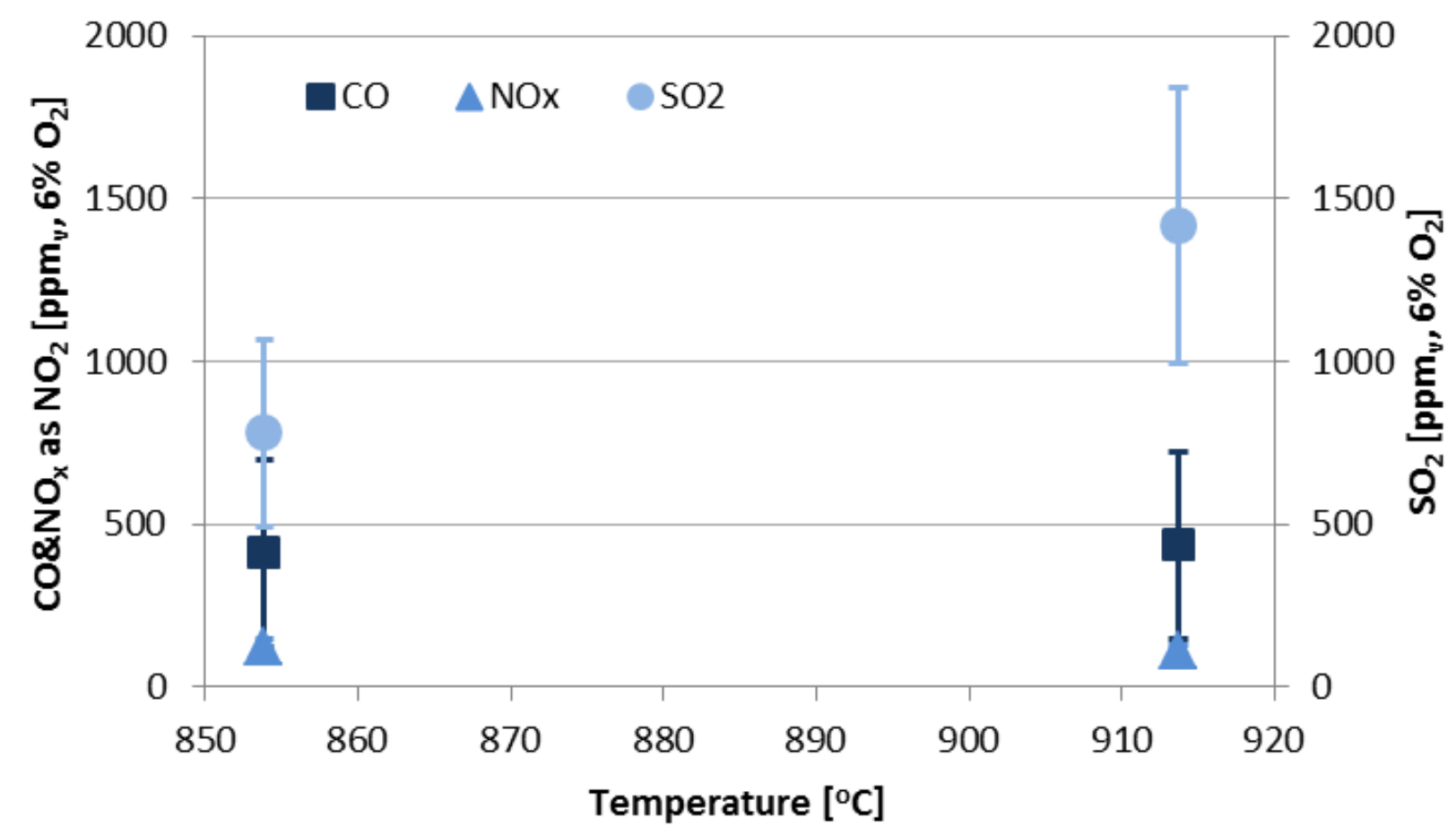

Figure 5. Effect of $\mathrm{O}_{2}$ percentage in gas on $\mathrm{CO}, \mathrm{SO}_{2}$, and $\mathrm{NO}_{\mathrm{x}}$ emissions for the co-combustion of wood pellets (50\% by wt.) and Spanish lignite

What is interesting in these results is the clear demonstration that co-firing biomass even up to the extent of $50 \%$ by weight does not significantly affect emissions, other than $\mathrm{SO}_{2}$. In this respect, this study is in agreement with earlier findings for a $0.8 \mathrm{MW}_{\text {th }}$ pilot-scale oxy-fuel CFBC [Tan et al., 2013].

As in the case of previous work [Tan et al., 2013], the volatile organic compound (VOC) emissions were also low and mostly well below current EU standards as shown in Table 6 below. (All runs in Table are cocombustion of lignite and wood pellets including 50\% wood pellets). The exception is one result for $\mathrm{CS}_{2}$, and benzene emissions. Comparing the VOCs emissions of our oxy-fuel CFBC with the limits set out in the European Union's Industrial Emissions Directive [Directive, 2010], which states that, for emissions of the VOCs where the mass flow of the sum of the compounds is greater than, or equal to, $10 \mathrm{~g} / \mathrm{h}$, a total sum emission limit value of $2000 \mu \mathrm{g} / \mathrm{Nm}^{3}$ shall be complied with, Table 6 shows that VOC emission rates from our oxy-fuel CFBC operation conform to this directive with the exception of results from the test CB-5 for benzene. Interestingly, much earlier work with a commercial-scale air-fired CFBC burning coal generally supported the idea that organic emissions are very low, with benzene being among the highest VOC emission [Cianciarelli, 1989; Mortazavi, 1996]. In this case it appears that neither oxy-firing nor K doping has made any significant difference to this outcome, but it is clear that attention should be paid to benzene emissions, although the one very high value, if it is not an artefact, could possibly be explained by the much smaller size of this unit compared with the $0.8 \mathrm{MW}_{\text {th }}$ scale of the CFB results provided by the Tan et al. work [2013] or operational problems in the test CB-5. As in the case of the work done by Tan et al. [2013], high benzene levels are also associated with slightly elevated toluene levels. 
Table 6. Hydrocarbon Emissions

$\operatorname{VOC}\left(\mu \mathrm{g} / \mathrm{Nm}^{3}\right)$

CB-3

CB-5

CB-7

CB-9

Dichlorodifluoromethane (FREON 12)

$0.54-0.90$

Chloromethane

Vinyl Chloride

$11.6-11.9$

$<82$

$<42$

$12-73$

$<0.44$

$<57$

Bromomethane

6.3

27

$8.9-70.1$

Chloroethane

$2.1-38.8$

$0.18-0.40$

$0.22-41.0$

Acetone (2-Propanone)

1,1-Dichloroethylene

20

Iodomethane

$<0.37$

$5.5-189$

Carbon Disulphide

12

9.7

Methylene Chloride (Dichloromethane)

$<0.64$

1,1-Dichloroethane

$<0.40$

trans-1,2-Dichloroethylene

cis-1,2-Dichloroethylene

$<0.34$

Chloroform

$<0.34$

1,2-Dichloroethane

$<0.37$

Methyl Ethyl Ketone (2-Butanone)

$<0.23$

1,1,1-Trichloroethane

Carbon Tetrachloride

Benzene

11

$<0.47$

$<0.54$

1,1,2-Trichloroethane

137

1,2-Dichloropropane

$<0.54$

Trichloroethylene

$1.3-1.5$

Dibromomethane

$<0.37$

Bromodichloromethane

$<0.34$

cis-1,3-Dichloropropene

$<0.37$

$<0.34$

trans-1,3-Dichloropropene

Dibromochloromethane

$<0.23$

$<0.30$

$<45$

$6.4-67.5$

14900

$<78$

$<49$

$<41$

$<41$

$<45$

$<29$

$<148$

$<57$

$<66$

117000

$<66$

$<45$

$<45$

$<41$

$<45$

$<41$

$<29$

$<37$

$1.7-2.0$

Methyl Isobutyl Ketone

$7.9-8.4$

Methyl Butyl Ketone (2-Hexanone)

$8.6-8.8$

Ethylene Dibromide

$<0.34$

$<78$

$<127$

$<0.6$

Tetrachloroethylene

Chlorobenzene

$0.55-0.74$

1,1,1,2-Tetrachloroethane

$<0.34$

Ethylbenzene

$1.6-1.9$

$\mathrm{m} / \mathrm{p}$-Xylene

4.5

Styrene

$2.0-2.2$

o-Xylene

$1.2-1.4$

Bromoform

$<0.47$

1,1,2,2-Tetrachloroethane

$<0.47$

1,2,3-Trichloropropane

$<0.5$

1,3-Dichlorobenzene

$<0.67$

$<0.67$

7680

$<41$

$<74$

$<45$

$<41$

386

298

2040

$73-74$

$<57$

$<57$

$<61$

$<82$

$<82$

$<31$

$<27$

$4.6-35.8$

$<19$

$3.6-10.4$

$<6.2$

$0.79-7.55$

$<21$

$3.8-97.2$

$<23$ $<4.3$

$0.34-4.85$

1,4-Dichlorobenzene

$1.7-32.8$

$104-158$

$<40$

$1.4-21.7$

-21.7
$<5.2$

$<7.1$

$11-23$

$<25$

$<9.0$

$<25$

$<21$

$<21$

$<23$

$<15$

$<4.7$

$<4.7$

$<5.2$

$<3.3$

$<75$

$<29$

$<34$

$<6.6$

$<34$

3060

$<34$

$<23$

$<23$

$<21$

$<23$

$<21$

$<15$

$<19$

$<7.6$

797

$<7.6$

$<5.2$

$<5.2$

$<5.2$
$1<4.7$

$<5.2$

$<4.7$

$0.5-39.9$
$<65$

$<3.3$

97

$<21$

$<38$

$<23$

$<21$

$<29$

$<31$

$<25$

$<9.0$

7

$30.9-31.2$

$<15$


CB-3: (air-fired)

CB-5: (oxy-fired, $25 \% \mathrm{O}_{2}$ )

CB-7: $\mathrm{K}$ doping (oxy-fired, $30 \% \mathrm{O}_{2}$ )

CB-9: $\mathrm{K}$ doping and limestone addition (oxy-fired, $30 \% \mathrm{O}_{2} ; \mathrm{Ca} / \mathrm{S}=3$ )

\subsection{Bed Solid, Fly Ash and Deposit Probe Results}

Bed ash and fly ash samples were taken at the end of co-combustion experiments for Tests no. 3-1, 3-2 and 3-3 which were nominal $24 \mathrm{~h}$ runs. At the end of each run, bed ash was separated into three groups according to particle size and they were exposed to XRF and XRD analyses. XRF analyses of three different particle ranges of bed ash are given in Table 7.

Table 7. XRF Analysis of Bed Ash

\begin{tabular}{llrrr} 
& & \multicolumn{3}{c}{ Particle Size of Bed Ash } \\
\cline { 2 - 5 } & & $\mathbf{0 . 6 - 0 . 8 5} \mathbf{~ m m}$ & $\mathbf{0 . 8 5 - 2 ~} \mathbf{~ m m}$ & $>\mathbf{2 m m}$ \\
\hline \multirow{3}{*}{ Test no. 3-1 } & $\mathrm{CaO}, \mathrm{wt} \%$ & 1.46 & 15.42 & 40.68 \\
\cline { 2 - 5 } & $\mathrm{SO}_{3}, \mathrm{wt} \%$ & 2.34 & 9.42 & 17.61 \\
\cline { 2 - 5 } Test no. 3-2 & $\mathrm{LOF}$ & 0 & 3.04 & 15.53 \\
\cline { 2 - 5 } & $\mathrm{CaO}, \mathrm{wt} \%$ & 1.46 & 15.42 & 40.68 \\
\cline { 2 - 5 } & $\mathrm{SO}_{3}, \mathrm{wt} \%$ & 2.34 & 9.42 & 17.61 \\
\hline \multirow{3}{*}{ Test no. 3-3 } & $\mathrm{LOF}$ & 0 & 3.04 & 15.53 \\
\cline { 2 - 5 } & $\mathrm{CaO}, \mathrm{wt} \%$ & 1.46 & 15.42 & 40.68 \\
\cline { 2 - 5 } & $\mathrm{SO}_{3}, \mathrm{wt} \%$ & 2.34 & 9.42 & 17.61 \\
\hline & $\mathrm{LOF}$ & 0 & 3.04 & 15.53 \\
\hline
\end{tabular}

LOF: loss on fusion

What is clear from these results at $850^{\circ} \mathrm{C}$ is that the Ca component in the bed ash for Test no. 3-2, where limestone was used is in the form of $\mathrm{CaCO}_{3}$ as indicated by the high loss on fusion (LOF) result and this has been confirmed by QXRD data, which show negligible $\mathrm{CaO}$ content in Test no. 3-2, (Table 8). For Test no. 3-3 (at $915^{\circ} \mathrm{C}$ ), Table shows a negligible $\mathrm{CaCO}_{3}$ content in the bed material.

Table 8. QXRD Composition as a Function of Bed Particle Size Range

Particle Size of Bed Ash

\begin{tabular}{llrrr} 
& & $\mathbf{0 . 6 - 0 . 8 5} \mathbf{~ m m}$ & $\mathbf{0 . 8 5 - 2} \mathbf{~ m m}$ & $\mathbf{2} \mathbf{2 m m}$ \\
\hline \multirow{2}{*}{ Test no. 3-2 } & Calcite, wt\% & 54.9 & 73.4 & 60.2 \\
\cline { 2 - 5 } & Lime, wt\% & 0.6 & 0.2 & 0.3 \\
\hline \multirow{2}{*}{ Test no. 3-3 } & Calcite, wt\% & - & - & 0.8 \\
\cline { 2 - 5 } & Lime, wt\% & 10.9 & 18.5 & 39.1 \\
\hline
\end{tabular}


For the fly ash, $\mathrm{CaO}$ content for Test no. $3-2$ is $14.5 \%$ (34.6\% sulphated) and the LOF is $10.8 \%$, while for Test no. 3-3, the $\mathrm{CaO}$ content is higher at $28.1 \%$, but this material is $37.8 \%$ sulphated and the LOF is lower at $8.1 \%$. QXRD results for these tests give the fly ash anhydrite content as $34.6 \%$, and the calcite content as $18.8 \%$, with the remaining compounds being small amounts of quartz $(7 \%)$, magnetite $(8.3 \%)$ and hematite $(4.4 \mathrm{~S} \%)$ for Test no. 3-2. For Test no. 3-3, the anhydrite content according to QXRD results is 54.5\%, with a lime content of $6.2 \%$, and a calcite content of $10.5 \%$, and the only iron compounds being hematite, at a concentration of $5.3 \%$ and magnetite at $6.4 \%$.

Probe results are given in Table 9. What is interesting about these results is that the primary component of the deposit is anhydrite, and that there is only a small amount of $\mathrm{K}$-containing material in the form of microcline in any of the deposits. In the $\mathrm{K}$ doping experiments fly ash contains between 1.5 and $2.5 \% \mathrm{~K}$ expressed as $\mathrm{K}_{2} \mathrm{O}$, compared with a value of $0.9 \%$ for the coal ash, and values for the bed ash of around 0.2 to $1.5 \%$ for all runs. However, this cannot totally rule out the possibility that some of the $\mathrm{K}$ is depositing elsewhere in the system.

Table 9. QXRD Result for Deposits on Deposit Sampling Probe

\begin{tabular}{llrrr}
$\begin{array}{l}\text { Chemical } \\
\text { Compound }\end{array}$ & & $\begin{array}{r}\text { Test no. 3-1 } \\
(\mathbf{w t} \%)\end{array}$ & $\begin{array}{r}\text { Test no. 3-2 } \\
(\mathbf{w t} \%)\end{array}$ & $\begin{array}{r}\text { Test no. 3-3 } \\
(\mathbf{w t \%})\end{array}$ \\
\hline Hematite, syn & $\mathrm{Fe}_{2} \mathrm{O}_{3}$ & 20.0 & 11.0 & 7.8 \\
\hline Anhydrite & $\mathrm{CaSO}_{4}$ & 13.0 & 33.8 & 36.9 \\
\hline Magnesioferrite, syn & $\mathrm{MgFe}_{2} \mathrm{O}_{4}$ & 5.6 & 12.7 & 4.9 \\
\hline Forsterite, syn & $\mathrm{Mg}_{2}\left(\mathrm{SiO}_{4}\right)$ & 9.8 & 8.8 & 9.7 \\
\hline Calcite & $\mathrm{CaCO}_{3}$ & 1.0 & 13.2 & 7.7 \\
\hline Quartz, low & $\mathrm{SiO}_{2}$ & 1.3 & 5.0 & 1.8 \\
\hline Lime, syn & $\mathrm{CaO}$ & 0.6 & 1.5 & 5.9 \\
\hline Microcline & $\left.\mathrm{K}_{(\mathrm{AlSi}}\right) \mathrm{O}_{8}$ & 2.7 & 4.2 & 2.4 \\
\hline & $\mathrm{Crystallinity}(\%)$ & 54.0 & 90.2 & 77.1 \\
\hline & Amorphous $(\%)$ & 46.0 & 9.8 & 22.9 \\
\hline
\end{tabular}

Similar tests carried out in a $0.1 \mathrm{~m}$ dia. air-fired CFBC in Turkey identified high concentrations of potassium calcium sulphate (30-70\%), using an identically designed air-cooled probe as in this work, also operating at a temperature of $550^{\circ} \mathrm{C}$. However, no such compound is apparent in these deposits, which suggests there is either a difference between oxy- and air-fired combustion, or the doping technique produces different results.

\section{Conclusions}

In the case of flue gas emissions for the combustion and co-combustion of Spanish lignite and wood pellets, the effect of the share of wood pellets in the fuel mixture on $\mathrm{CO}_{2}, \mathrm{CO}, \mathrm{SO}_{2}$, and $\mathrm{NO}_{\mathrm{x}}$ emissions was investigated. These results suggest increasing biomass share in the fuel mixture had no impact on $\mathrm{NO}_{\mathrm{x}}$ emissions, and only a small positive impact on $\mathrm{CO}$ emissions. As expected, $\mathrm{SO}_{2}$ emissions decreased with an increase in the share of wood pellets in the fuel mixture. 
Experiments with $\mathrm{K}$ doping of the biomass did not show any significant effect on gas emissions, as expected, and the deposits formed were comprised principally of anhydrite, with a low amount of a $\mathrm{K}$ component (microcline). As the $\mathrm{K}$ levels in the fly ash were only slightly elevated in the $\mathrm{K}$ doping experiments this means we cannot completely rule out the possibility that $\mathrm{K}$ is depositing elsewhere in the system.

$\mathrm{SO}_{2}$ emissions increased from about $300 \mathrm{ppm}$ (air firing, 21\% $\mathrm{O}_{2}$ with $50 \%$ biomass addition) to $2300 \mathrm{ppm}$ when the co-combustion test (50\% wood pellets) was conducted with $25 \% \mathrm{O}_{2}$. This increase is due to flue gas recycle and one might conclude that this can also be explained in part by the high partial pressure of $\mathrm{CO}_{2}$ in the combustor which, in turn, promotes direct sulphation. However, increasing the bed temperature to $915^{\circ} \mathrm{C}$ also increased the $\mathrm{SO}_{2}$ emissions, even though at the higher bed temperature the sulphation must have been by the indirect route. The $\mathrm{O}_{2}$ percentage in the gas had no significant effect on $\mathrm{NO}_{\mathrm{x}}$ emission. Increasing the $\mathrm{O}_{2}$ percentage in the gas supplied to the base of the combustor appeared to cause some increase in $\mathrm{CO}$ emission. Finally, while an increase in the operating temperature from $850^{\circ} \mathrm{C}$ to $915^{\circ} \mathrm{C}$ increased the $\mathrm{SO}_{2}$ emissions it did not significantly affect the $\mathrm{CO}$ and $\mathrm{NO}_{\mathrm{x}}$ emissions. Overall, these experiments suggest that co-firing biomass in CFBC in an oxy-fuel environment poses no special problems, which is in line with other, albeit limited work on pilot oxy-fuel CFB plants that has been generated.

Hydrocarbon emissions were also low, with the exception of benzene, as was anticipated based on previous CFBC results. A general conclusion can be drawn from these results, namely that there is simply a dearth of studies on emissions of oxy-fired CFB plants operating in the co-firing mode and, in particular, information on organic emissions of which this study and an earlier study by Natural Resources Canada CanmetENERGY on its $0.8 \mathrm{MW}_{\text {th }}$ CFBC unit appear to be the only two public domain studies currently available.

\section{Acknowledgment}

The financial support provided to this project by the Turkish Scientific and Technical Research CouncilTUBITAK-2214 (2011/2) is greatly appreciated as is the support of Natural Resources Canada CanmetENERGY, where the test work was carried out and which hosted Dr. Varol during the course of this work. 


\section{References}

1. Al-Jeboori, M.J., Nguyen, M., Dean, C. and Fennell, P.S., Improvement of Limestone-based $\mathrm{CO}_{2}$ Sorbents for $\mathrm{Ca}$ Looping by $\mathrm{HBr}$ and Other Mineral Acids, Industrial and Engineering Chemistry Research, 52, 1426-1433, 2013.

2. Anthony, E.J. and Granatstein, D.L., Sulfation Phenomena in Fluidized Bed Combustion Systems, Progress in Energy and Combustion Science, 27, 215-236, 2001.

3. Anthony, E.J. and Hack, H., Oxy-fired Fluidized Bed Combustion: Technology prospects and new developments, Chapter 5 (pg. 867-894) in Fluidized Bed Technologies for Near-Zero Emission Combustion and Gasification, F. Scala (ed.), Woodhead Publishing, London, UK, 2013.

4. Bui, M., Fajardy, M., MacDowell, N., "Bio-Energy with CCS (BECCS) Performance Evaluation: Efficiency Enhancement and Emissions Reduction, Applied Energy 195, 289-302, 2017.

5. Cianciarelli, D., Characterization of Semi-Volatile Organic Emissions from the Chatham $20 \mathrm{MW}$ Circulating Fluidized Bed Demonstration Unit, Environment Canada Report, File 4030-7-15, January 1989.

6. Cormos, C-C., Oxy-combustion of Coal, Lignite and Biomass: A Techno-economic Analysis for a Large-Scale Carbon Capture and Storage Project in Romania, Fuel, 169, 50-57, 2016.

7. Demirbas, M.F., Evaluation of Olive Cake for Bio Oil, Energy Sources, Part A, Recovery, Utilization and Environmental Effects, 31, 1236-1241, 2009.

8. Directive 2010/75/Eu of The European Parliament and of The Council of 24 November 2010 on industrial emissions (integrated pollution prevention and control), Official Journal of the European Union, 17.12.2010.

9. Duan, L., Duan, Y., Zhao, C., and Anthony, E.J., NO emissions during co-firing in an Oxy-fuel Circulating Fluidized Bed Combustor, Fuel, 150, 8-13, 2015.

10. https://www.epa.gov/sites/production/files/2015-12/documents/0031.pdf accessed November 2017.

11. García-Labiano, F., Rufas, A., De Diego, L.F., Obras-Loscertales, M.D.L., Gayán, P., Adánez, J., Calcium-based Sorbents Behaviour during Sulphation at Oxy-Fuel Fluidized Bed Combustion Conditions, Fuel, 90, 3100-3108, 2011.

12. Jia, L., Tan, Y., Wang, C. and Anthony, E.J., Experimental Study of Oxy-Fuel Combustion and Sulfur Capture in a Mini-CFBC, Energy \& Fuels. 21, 3160-3164, 2007.

13. Jia, L., Tan, Y. and Anthony, E.J., Emissions of $\mathrm{SO}_{2}$ and $\mathrm{NO}_{\mathrm{x}}$ during Oxy-Fuel CFB Combustion Tests in a Mini-Circulating Fluidized Bed Combustion Reactor, Energy \& Fuels. 24, 910-915, 2010.

14. Jia, L., Tan, Y., McCalden, D., Wu, Y., He, I., Symonds, R. and Anthony, E.J., Commissioning of a $0.8 \mathrm{MW}_{\text {th }}$ CFBC for Oxy-Fuel Combustion, International Journal of Greenhouse Gas Control, 7, 240-243, 2012.

15. Leckner, B., Co-Combustion - A Summary of the Technology, AGS Pathways report 2007:E3.

16. Leckner, B. and Karlsson, M., Gaseous Emissions from CFB Combustion of Wood, Biomass and Bioenergy, 4, 379-389, 1993.

17. Lu, D.Y., Hughes, R.W., Anthony, E.J. and Manovic, V., Sintering and Reactivity of $\mathrm{CaCO}_{3}$ based Sorbents for Insitu $\mathrm{CO}_{2}$ Capture in Fluidized Beds under Realistic Calcination Conditions, Journal of Environmental Engineering, 135, 404-410, 2009.

18. Lupiáñez, C., Guedea, C., Bolea, I, Luis, I., Díez, L.I. and Romeo, L.M., Experimental study of $\mathrm{SO}_{2}$ and $\mathrm{NO}_{\mathrm{x}}$ emissions in fluidized bed oxy-fuel combustion, Fuel Processing Technology, 106, 587594, 2013.

19. Lupion, M., Alvarez, I., Otero, P., Cortes, V.J., Kuivalainen, R., Lantto, J., Hotta, A. and Hack H., 30 MW $_{\text {th }}$ Ciuden Oxy - CFB Boiler- First Experience, GHGT-11, Energy Procedia, 2013.

20. Mortazavi, R., Characterization of Semi-Volatile Organic Compounds (SVOCs) and Volatile Organic Compounds (VOCs) from the Point Aconi Coal-Fired Power Plant, Environment Canada Report PMD/96-7, 1996. 
21. Romeo, L., Diaz, L.I., Guedea, I. Bolea, I., et al., Design and operation assessment of an oxyfuel fluidized bed combustor, Experimental Thermal and Fluid Science, 35, 477-484, 2011.

22. Singh, R.I. and Kumar, R., Current Status and Experimental Investigation of Oxy-Fired Fluidized Bed, Renewable and Sustainable Energy Reviews, 61, 398-420, 2016.

23. Stanmore, B.R. and Gilot, P. Review-Calcination and Carbonation of Limestone during Thermal Cycling for $\mathrm{CO}_{2}$ Sequestration, Fuel Processing Technology, 86, 1707 - 1743, 2005.

24. Symonds, R.T., Champagne, S., Ridha, F.N. and Lu, D.N., Attrition of CaO-based pellets in a $0.1 \mathrm{MW}_{\text {th }}$ dual fluidized bed pilot plant for post-combustion $\mathrm{CO}_{2}$ capture, Powder Technology, 291, 60-65, 2016.

25. Toftengaard, M., Brix, J., Jensen, P.A., Glarborg, P. and Jensen, A.D., Oxy-fuel Combustion of Solid Fuels, Progress in Energy and Combustion Science, 36, 581-625. 2010.

26. Tan, Y., Jia, L. and Anthony, E.J., Experiences and Results on a $0.8 \mathrm{MW}_{\text {th }}$ Oxy-fuel Operation PilotScale Circulating Fluidized Bed, Applied Energy, 92, 343-347, 2012.

27. Tan, Y., Jia, L. and Wu, Y., Some Combustion Characteristics of Biomass and Coal Cofiring under Oxy-Fuel Conditions in a Pilot-Scale Circulating Fluidized Combustor, Energy \& Fuels. 27, 7000, 2013.

28. Varol, M., Investigation of Combustion Characteristics of Biomass and Coal Mixtures in a Circulating Fluidized Bed Combustor, PhD Thesis, Middle East Technical University, Turkey, September 2013.

29. Varol, M., Atimtay, A.T., Olgun, H., Atakül, Emission Characteristics of Co-Combustion of a LowCalorie and High-Sulfur Lignite Coal and Wood Pellets in a Criculating Fluidized Bed Combustor: Part 1. Effect of Excess Air Ratio, Fuel, 117, 792-800, 2014a.

30. Varol, M., Atimtay, A.T., Olgun, H., Emission Characteristics of Co-Combustion of a Low-Calorie and High-Sulfur Lignite Coal and Wood Pellets in a Circulating Fluidized Bed Combustor: Part 2. Effect of Secondary Air and Its Location, Fuel, 130, 1-9, 2014 b. 